\title{
Decentralization in International Relations: A Study of Semarang City's Paradiplomacy
}

\author{
Hermini Susiatiningsih ${ }^{1}$, Nadia Farabi ${ }^{1}$, Satwika Paramasatya ${ }^{1}$, and Sheiffi Puspapertiwi ${ }^{1}$ \\ ${ }^{1}$ Department of International Relations, Universitas Diponegoro, Semarang-Indonesia
}

\begin{abstract}
Democratization in developing countries triggered by globalization has led decentralization. Post New-Order Indonesia chose decentralization as its policy to improve democratization, allowing transfer of authority to its local governments, thus raises roles taken by sub-state actors, including in international relations. States, regions, provinces and cities seek their way to promote trade, investments, cooperation, and in some cases, political support, through cross-borders contacts with their international counterparts. The phenomenon which later understood as "paradiplomacy" is thus defined as communication conducted by sub-state actors aimed to promote identity and or pursuing local interests. This study analyze how Semarang, as a melting pot city in Java, positioned itself in international community and develop its own paradiplomacy. The study finds that Municipal Government of Semarang with authority expanded by decentralization uses paradiplomacy as a mean to achieve economic interest, especially to expand market and attract foreign investment, with its environmental issue that remains leftbehind. The prototype of paradiplomacy is found in "SemBiz", annual expo in trade and investment held by Municipal Government of Semarang. Not only serves economic development in Semarang, paradiplomacy is also utilized to preserve, if not strengthen, its locality as integral part of Semarang's identity.
\end{abstract}

Keywords: Decentralization, Paradiplomacy, Locality, Semarang

\section{Introduction}

In this era, most of State in the world begins to concern on low politics issues which are more threatening for society welfare. Those issues have caused an actor friction of international relations. Before globalization era, State has a very dominant power, but the raising power of new actors, such as nongovernmental organizations (NGOs) and multinational corporations (MNCs), create a new atmosphere on diplomatic course. Recently, diplomacy is not exclusive for government to government relations, but expands to cover relation of government to non-government, nongovernment to non-government, government to people, and people to people relations.

In a huge populated and large state, central government has a limitation to directly reach some of local issues. Based on that fact, local governmental system is needed by applying decentralization and local autonomy. Decentralization is a guideline for creating political equality, local accountability and local responsiveness to provide public goods and services [1]. The system can help the realization of local democracy goals, i.e. (1) increasing public participation on political process; (2) increasing public accountability; and (3) increasing society welfare.

Semarang as capital city of Central Java and also a metropolitan and the fifth biggest city in Indonesia has some uniqueness. Geographically, Semarang is located in a strategic position which causes this city as an economic point of Java Island and as national region point for the Central in creating relationship with other regions and the foreign. Based on demographical aspect, Semarang becomes a multicultural and multi-ethnic city. This city also offers many attractive tourism destinations which can be used to increase regional income.

However, Semarang also has many environmental local problems, such as flood, degradation of underwater quality, waste, river pollution, and bad infrastructure. For those, local government should conduct cross border cooperation to realize the fulfilment of society needs, especially environmental issues that are frequently ignored should be paid attention more side by side with economic matters. Central Java has conducted some international cooperation, especially with Fujian Province, People's Republic of China. Sister city cooperation between three regions (Semarang, Surakarta and Bumiayu) also

\footnotetext{
*Corresponding author: sheiffi.pertiwi@gmail.com
} 
created. In globalization era, central cities like Semarang have a bigger responsibility to maintain its localities. Conducting foreign partnership is also important to strengthen Semarang's locality by implementing paradiplomacy.

\section{Methodology}

This is a qualitative research with secondary data. Locality is close to a characteristic place. In this context, Semarang's locality can be classified as the unsure of character building and dynamic interaction between static unsure (geographic) and dynamic unsure (socialculture, economic and politics). Semarang City is located at the northern coast of Java Island and becoming a trade gate which causes Semarang has an important position on local culture development. Interaction between newcomer and indigenous people makes Semarang as a melting point of Javanese, Arabic, Chinese and Dutch culture. Acculturation of Chinese and Javanese culture has a dominant effect of the Semarangan culture development. It can be seen on its culinary, i.e. loempia (lumpia), kue moci, wingko babad, and also lontong cap go meh. The acculturation is also implemented on its architecture, as Sam Poo Kong and Kampung Pecinan.

\section{Discussion}

Semarang as a melting point of assimilation between Javanese and Dutch culture can be reached on the racial segregation of colonial government in between white skin nation, indigenous people and other nations (including Chinese and Arabian). It was created in social stratification to delimit cross group interaction. The delimitation was aimed to maintain the natural culture of colonial and also as a hegemonic instrument. Dutch architecture is commonly used for hegemonic symbol in many buildings.

Assimilation and acculturation has formed the characteristic of local culture which make differences between Semarang and other regions. The cultural process is classified as one of social-culture modality on paradiplomacy for promoting Semarang in global level. Its cultural values can be arranged as a romantic modality for economic modality.

Semarang's local economic modality is also affected by geographic and demographic condition. Its condition is at risk as Semarang is situated in the area of impact of floods due to coastal land problems. To overcome it, Semarang has been working on several numbers of efforts, such as flood warning system, rainwater harvesting, and mangrove planting. However it is also as sign to create encouraging strategy chance on city development by the integration of near regions, as known the hinterland of Semarang.

Semarang city concerns on developing support infrastructure for economic and service activity by using city layout plan. As a trade and government point of Central Java, Semarang city has limited number of land in rural area to be maintained as agriculture land. The near regions, such as Kendal, Demak, Salatiga and Grobogan (Kedungsepur), are involved as support function. Meanwhile, its region is more functioned as administration and business center.

As investment and trade city, the land of Semarang City is more functioned for industry area. The increasing of investment flow in latest decade causes this industry area with 1.029 hectares of large has been crowded [2]. Semarang city government starts to promote the development of hinterland industry. In other side, that fact is used to be a modality for enhancing paradiplomacy through Meetings, Incentives, Conferences, and Events (MICE).

MICE Program is chosen by two factors. The first is economic life of Semarang is dominated by trade and business activities. Secondly, the main offered attraction of MICE Program is business by fun excursion. The advantages of this program can be used to revitalize the popular tourism objects of Semarang.

Semarang Pesona Asia (SPA) was launched in 2007 for promoting Semarang city in national and international level. For realizing the goal, Semarang Business Forum (Sem'Biz) was established and successfully on making LoI as commitment of the investors to make investment in Semarang and around. In 2014, Sem'Biz totally produced Rp 2.93 trillion for property investment [3]. In fact, local diplomacy probably occurs in this democratization period. UU No. 23 Tahun 2004 Article 10 Paragraph 1 becomes a limitation for local government independence by the reason of foreign policy is still as absolute authority of center government [4]. However, UU No. 24 Tahun 2000 on International Agreement, UU No. 32 Tahun 2004 on Local Goverment, Peraturan Menlu RI No. 09/A/KP/XII/2006, Permendag No. 3 Tahun 2008, Permendag No. 74 Tahun 2012 can be used as a legal base of transnational relation between local government and other global actors. This relation is currently known as paradiplomacy.

Paradiplomacy is commonly used in relation of local government and other international actors for achieving local interests [5]. Local diplomacy is concerned on its actors, meanwhile paradiplomacy has a concern on parallel relation with conventional diplomacy. Hereinafter, this research is focused on "relation" itself and using a definition of paradiplomacy by A. Kuznetsov as "a form of political communication for reaching economic, cultural, political, or any other types of benefits, the core of which consists in self-sustained actions of regional governments with foreign governmental and non- governmental actors" [6]. From the definition, the aim of paradiplomacy is to gain economic and political advantage.

On the first layer of paradiplomacy, sub-nation government commonly has a motivation to build an international existence in order to attract investment and foreign companies and also to open a new export market. The second layer is the tied interaction has been focused on enhancing people to people relation in culture, education, technology and more aspects. The second layer is advocating local identity to international level, which has difference with central government 
perception. In this context, sub-nation government attempts to establish international relation that can promote the different culture, political autonomy and communal characteristic [7].

Based on the above description, the main goal of paradiplomacy is to attract global society interest over the regional uniqueness in order to be included in global level. Paradiplomacy attempts to modify terra incognita as an interesting space with all its potential and problematical issues [8]. However, the increasing of paradiplomacy phenomenon in this digital era also evokes some crucial problems.

The problem can be classified as vertical and horizontal problem. The raising of noise on global diplomacy arena is can be included to horizontal problem. There are more actors with various proposal goals that can make difficult of choosing prospective region for paradiplomacy. In the other side, sub-nation government has to make efficiency on utilizing the limited resources. So, a strategic planning must be conducted in order to prevent of a failed paradiplomacy by preparing a great cooperation proposal and also build a strategic thinking for partner seeking.

Sem'Biz has had a good framework as modality to conduct paradiplomacy for Semarang City and around. Sem'Biz can be included as a prototype for effective method by the reason of its success on supporting Semarang City and Greater Semarang in national business map. The number of national investment and its progress is a real evidence of the effective communication in between stakeholders. Each regency or city government has identified their each potential.

By using UU No. 37 Tahun 1999 on Foreign Affair Mechanism, UU No. 24 Tahun 2000 on International Agreement, PeraturanMenlu RI No. 09/A/KP/XII/2006, Permendag No. 3 Tahun 2008, serta Permendag No. 74 Tahun 2012, Semarang City can enact a LoI to utilize globalization access and chance for paradiplomacy framework. This practice apparently has been implemented on Sem'Biz Program by launching a LoI on investment agreement. From the agreed LoI, Semarang City obtains economic advantage through capital flow for developing local economy. Furthermore, the government can attempt for providing job vacancy, improving public facility, and upgrading social welfare service for society.

Sem'Biz has showed that cooperation by decentralization (which may be an international cooperation) can be a complement for central government diplomacy on promoting local potential for foreign business and investment activities. The raising of sub-nation actors are not only offering local potential information, but also providing a local problem understanding.

In other word, paradiplomacy prototype through Sem'Biz Program is mentioned by Lecours as the first layer of paradiplomacy which focus on the utility of economic competence. Becoming a trendmark investment policy in Central Java is one of Sem'Biz vision. According the vision, diplomacy will only focus on local economic interest by using investment for overcoming local problems, i.e. the limited ability of capital accumulation in regional and national level. Capital accumulation will be an important aspect for developing local potential by sufficient financial capital.

Semarang has had two main assets on developing paradiplomacy, specifically social-culture and economic asset. Social-culture consists of cultural identity as a melting pot city with its acculturation and assimilation between local society and the newcomers. Its historical and cultural value will be a romantic power that can emerge sentiment between the paradiplomacy actors as a consequence of cultural bonding by diaspora and balanced understanding of universal value. Meanwhile, economic modality consists of natural resource and non-natural resource as part of trade-off in paradiplomacy negotiation. Globalization as a chance to conduct a direct contact with other regional or international actors can be an alternative of investment resource more than internal capital accumulation. On other side, potential partner must obtain a guarantee that the offered local potential has a good prospect.

\section{Conclusion}

As capital province of Central Java, Semarang has locality that can be used as a proper way to enhance city development. Sem'Biz and Semarang Pesona Asia are evidences of Semarang survival for its locality in globalization and modernization era. Locality and paradiplomacy as united component to conduct diplomacy with other region and an alternative to develop each region. Semarang City can be a reflection of Central Java development. Central Java probably can be a successor for this initiation. Therefore, its success on enhancing locality becomes an inspiration for Central Java locality initiation. Thus, decentralization system has bolstered the emerging of paradiplomacy as an essential course of local government in recent time.

\section{References}

1. S. Hidayat, "Desentralisasi dan Otonomi Daerah dalam Perspektif State-Society Relation", Jurnal POELITIK Vol.1 No.1 (2008).

2. H. Lazuardi, "Kawasan Industri Kota Semarang Hampir Penuh", Retrieved from http://kabar24.bisnis.com/read/20140508/78/226142/ kawasan-industri-kota-semarang-hampir-penuh (2014).

3. Pemerintah Kota Semarang, "Laporan Kegiatan: 8th Semarang Business Forum", Semarang: Badan Pelayanan Perizinan Terpadu Kota Semarang (2014).

4. L. M. Fathun, "Paradiplomasi Menuju Kota Dunia: Studi Kasus Pemerintah Kota Makassar", Indonesian Perspective 1(1): 75-94 (2016).

5. V. P. Rogier, and J. Melissen, "City Diplomacy: The Expanding Role of the Cities in International Politics", Hague: Netherlands Institute of International Relations (2007).

6. A. S. Kuznetsov, "Theory and Practice of Paradiplomacy: Subnational Governments in International Affairs", New York: Routledge (2015).

7. A. Lecours, "Political Issues of Paradiplomacy: Lessons from the Developed World", 
8. A. Sergunin, and P. Joenniemi, "Paradiplomacy as a Sustainable Development Strategy: The Case of Russia's Arctic Sub-national Actors" Eurasia Border Review pp. 1-17 (2014).

9. R. Tavares, "Paradiplomacy: Cities and States as Global Players", New York: Oxford University Press (2016). 